\title{
Black Cowboys in the American West: An Historiographical Review
}

\author{
David Goldstein-Shirley \\ University of Washington, Bothell
}

\begin{abstract}
Few subjects in the ethnic experience of the United States are as fraught with mythology and misinformation as black cowboys. Although absent from most classic history texts of the American West, black cowboys probably constituted about a quarter of the working cowboys in the nineteenth century, although quantitative data to establish a number are lacking. This essay reviews the historiography of black cowboys published during the last half-century, noting how much of it is marred either by glossing over the presence of black cowboys or by credulously repeating estimates of their numbers established by earlier work. The essay speculates whether such problematic scholarship stems from unacknowledged prejudice among mainstream historians or from carelessness and calls for more and improved scholarly attention to the role of African American cowboys in the American West.
\end{abstract}

Of the estimated 35,000 cowboys on the Western American frontier during the second half of the nineteenth century probably several thousand were black, although figures offered by several historians must be regarded as no more than conjectures. ${ }^{1}$ A potentially high percentage of Blacks in the cattle business is remarkable, especially considering that in both 1860 and 1910 they constituted less than one percent of the West's population. ${ }^{2}$ Yet scholarly attention to them has been intermittent and patchy at best. After a handful of texts on the topic were published in the 1950s and 1960s, interest waned, and even some recent, major works on the American West give short shrift to black cowboys. Two books published in the last five years, however, signal that a new generation of scholars is willing to advance understanding of Blacks in western history. Richard W. Slatta's (1990) Cowboys of the Americas presents a comparative study of cowboys throughout the Americas and includes discussions of race and race relations on the U.S. frontier.

Ethnic Studies Review Volume 20 (1997): 79-89. 
Artistic output by and about cowboys is the focus of The Cowboy: Representations of Labor in an American Work Culture by Blake Allmendinger (1992). Although his book focuses upon the culture of cowboys rather than on the historical record, his understanding of myth leads him to correct much sloppy and erroneous scholarship that characterizes earlier works. Yet the picture of black cowboys as resistors of oppression remains shrouded in an overly-mythologized West.

Although no longer chattel, freed Southern Blacks at the beginning of Reconstruction immediately faced the multiple crises of disenfranchisement, segregation, and poverty. Without access to land ownership upward mobility was impossible for the great majority of blacks. Eric Foner writes that 'blacks in the Redeemers' New South found themselves enmeshed in a seamless web of oppression, whose interwoven economic, political, and social strands all reinforced one another." $3 \mathrm{He}$ notes that, faced with little or no opportunity to resist such weighty oppression, some Blacks in the post-Reconstruction South considered migration to Africa or to the West.

Although mass migration of black Americans to the West never materialized except for about 20,000 black "exodusters" who migrated to Kansas in 1879 and $1880^{4}$, small numbers of individuals did move to the frontier states. There they joined Blacks who had worked as slaves on Western ranches. Suddenly free men, many blacks continued to work as ranch hands, but for wages. Although the West was no utopia for blacks, it offered far greater opportunities for dignity and livelihoods than did the New South.

Biographies and autobiographies of black cowboys appeared as early as the turn of the century, and many accounts of white cowboys' lives refer to black workmates. ${ }^{5}$ Except for a few isolated articles, however, mainstream scholarly journals for decades bore no evidence that historians were aware of this aspect of western history. Not only were black cowboys ignored, black soldiers, ranchers, and farmers went virtually unmentioned in the traditional academic literature.

In early twentieth-century history texts, Blacks received some attention, although it was unsustained. In his 1922 work of popular writing, The Cowboy, Philip Ashton Rollins merely mentions in passing that "a more than occasional negro" numbered among the "men of the Range." Rollins' work is laced with folklore and myth, but even serious scholars failed to provide a more accurate portrayal of the West. For example, in Walter Prescott Webb's monumental The Great Plains of 1931, he praises Rollins but makes no mention of African Americans. ${ }^{6}$

The black civil rights movement of the 1950 s and 1960 s sparked some interest in topics of African American history, but the advances made in recognizing Blacks' place in western history were "uneven." Much of the western settlement story remains to be told; even respected works published since 1965 pay little attention to Blacks in the cattle 
industry. Robert R. Dykstra's The Cattle Towns (1968), which covers the growth and decline of several Kansas towns, overlooks the part that Blacks played in the story of that region. ${ }^{8}$ Richard A Bartlett's social history of the frontier up to 1890 , The New Country (1974), merely mentions that a quarter of the cowboys on the trails were Black and that "the blacks were good frontiersmen." ${ }^{\prime 2}$ Even the 1988 magnum opus of Rodman W. Paul, The Far West and the Great Plains in Transition, 18591900 , notes only that a black former slave, Bose Ikard, rode with Charles Goodnight and Oliver Loving in their establishment of the GoodnightLoving Trail. ${ }^{10}$ In fact, though, Blacks not only rode the trails; they were instrumental in the creation of all of the major cattle trails. Paul's only other reference to Blacks in the cattle business is his notation that they "frequently served with cattle outfits, most often as cooks, sometimes as remuda men [wranglers], and perhaps a few thousand as cowboys."11 Finally, David Dary's specific look at cowboys, Cowboy Culture (1981), mentions little more about Blacks than that the descendants of slaves brought to Texas "were probably among the first black cowboys." ${ }^{12}$ Earlier scholars, however, had already established the fact that some slaves themselves became cowboys. Dary apparently overlooks the work that had demonstrated-albeit in a spotty manner-the numerous contributions of black cowboys.

A handful of other scholars began to fill the void regarding black cowboys. One of the topic's two principal rediscoverers was Philip Durham. In a sketchy essay that appeared in 1955, Durham briefly noted the conspicuous absence of post-World War II material on the black cowboy. Interestingly, Durham was a professor of English, not of history. Because at the time he was occupied with writing a book unrelated to black cowboys, Durham did not return to the topic that he had rediscovered until, with Everett L. Jones, he wrote a 1964 essay title, "Negro Cowboys," and a book, The Negro Cowboys, which was published in 1965. ${ }^{13}$

The significance of the fact that it took two literature professors to produce the first book about the history of black cowboys was not lost on Durham and Jones:

As teachers of English, the authors came upon this subject through a long-standing interest in the backgrounds of Western American literature. Pursuing this interest we discovered, to our surprise, an unimagined number of Negro cowboys, who had been dropped from the history of the West. ${ }^{14}$

Their book, although seriously flawed, attempted to reinstate in western historiography the African American cowboys. 
Durham and Jones' account of the black cowboy is incomplete mainly because primary sources from a mostly illiterate profession are rare. The book remains important, however, because in its anecdotal way it clearly establishes a significant presence of Blacks among the cowboys. With Durham and Jones' account the story begins to unfold.

Beginning about fifteen years before the Civil War, Easterners began moving to the western frontier in increasing numbers seeking new opportunities. Many took slaves with them. "Most of the first Negro cowboys were slaves," write Durham and Jones. "Brought by their masters from the old south, they arrived in a new country and were set to learning a new trade," taught by Mexican vaqueros, by cattle-raising Indians, or by the masters themselves (14).

Most of the newcomers settled in southeastern Texas. The area grew rapidly.

\begin{abstract}
"When Texas entered the Union in 1845, it had about 100,000 white settlers and 35,000 slaves. By 1861 , when Texas seceded from the Union, it had more than 430,000 white settlers and 182,000 slaves," according to Durham and Jones.
\end{abstract}

In some areas all-black crews were common, and there even were some free black owners of cattle. Moreover, some black cattlemen owned slaves $(15,17)$.

The Union's victory in the Civil War left Blacks in Texas free but not well-off. "Most of them were illiterate, unskilled farm hands. Some were skilled artisans, others capable cowboys," but, whatever their lot, all Blacks in Texas faced "the bitter heritage of racial antagonism" during and following Reconstruction (22-3). Durham and Jones write the following although their evidence for this assertion goes uncited.

Upon Negro cowboys, however, [social, legal and economic] sanctions fell less heavily than upon many other Negroes, for as cowboys they held a well-defined place in an early established social and economic hierarchy (24).

Elsewhere, in fact, they contradict their claim that black cowboys suffered any discrimination. They continuously emphasize that black and white cowboys faced equivalent hardships and equivalent rewards in what the authors imply was a color-blind environment. ${ }^{15}$

Richard W. Slatta's account of frontier racism contradicts Durham and Jones' conclusions. "Frontier democracy is a myth," he writes; "As in society at large, whites imposed their will and rule on nonwhites." He claims that black cowboys suffered less economic discrimination than 
did Mexican vaqueros but in general "found no more upward social mobility on the frontier than elsewhere in society. ${ }^{16}$ Ironically, Slatta's principal source for his understanding of Blacks in the West was Durham and Jones despite his divergent interpretation of how Blacks were treated.

Although Durham and Jones provide the first reasonably comprehensive account of black cowboys, W. Sherman Savage had been researching and publishing on the topic a generation earlier. Savage published his first article, "The Negro in the History of the Pacific Northwest," in 1928 and soon expanded his studies to the entire West. His 1940 article, "The Negro in the Western Movement," although also tending toward anecdote, established a foundation for later scholars who eventually stumbled onto this "new" topic. ${ }^{17}$

It took fifteen years for a scholar such as Durham to follow Savage's lead. Had Durham not serendipitously come upon the topic, the Black cowboy might have remained obscure to the mainstream historian. It is clear that Durham relied heavily upon Savage, citing the elder scholar's publications several times in The Negro Cowboys. Writing his own book eleven years later on Blacks in the West, Savage refers to Durham and Jones only once, in his introduction; he had done the primary research long before. The renowned American historian Ray Allen Billington, who wrote the foreword to Savage's book, said of Savage: "He was, in the truest sense, a pioneer, blazing a path into an aspect of the past that had been too long neglected but that his successors were to follow." ${ }^{18}$

Two works, both published in 1971-William Loren Katz's The Black West and Kenneth W. Porter's The Negro on the American Frontier-cover in summary fashion the African American presence on the shifting frontiers of America. ${ }^{19}$ Savage, however, spent the thirty-six years between his "The Negro in the Westward Movement" article and his book studying little else, and his Blacks in the West (1976) is monumental. Savage's is the first book to give a comprehensive picture of Blacks in various occupations in the trans-Mississippi West.

Savage focuses on Blacks in the military, in business and industry, in politics, and in education. By describing the entire western milieu as faced by Blacks in the nineteenth century, Savage provides a solid background for understanding where the black cowboys fit. His book also serves as a more credible - because more rigorously documented-source when Durham and Jones are unclear, misleading, or incomplete. For example, Savage states that most antebellum free Blacks in the Far West "were distributed among the Pacific Coast states"20; this rounds out the picture presented by Durham and Jones who, because they look at slave in addition to free states, focus primarily upon Texas. On the other hand, Savage's work is both narrower in geographic scope and broader in its consideration of occupations than is Durham and Jones'. His book necessarily offers fewer, although more accurate, details specifically about black cowboys than does Durham and Jones'. 
Economic and social forces-such as increased settlement of the Plains which blocked major trails and improved transportation which obviated cattle drives -ended the heyday of the cowboy. Fiction resurrected the cowboy but in a romanticized, distorted-and bleached-form. In the nineteenth century, the mythical West began to replace the genuine West in the world's psyche.

Durham and Jones cite the absence of black cowboys in popular media as a reason for their absence in public consciousness. Fictional western tales in dime novels became extraordinarily popular in the East among credulous readers who knew nothing of the real life of the West, and in about 1,500 such novels published between 1860 and 1898 Durham found Blacks appearing only insignificantly. Beginning with Owen Wister's The Virginian in 1902, after the West already had been settled, the modern Western stories emerged but offered no improvement. They, too, with only a few exceptions, forgot the black cowboy. ${ }^{21}$ In fact Larry McMurtry's novel, Lonesome Dove, published in 1985 , is one of the first literary works that accurately portrays the racial composition of typical Western cattle drives, and its television serialization marks one of the first accurate representations on that medium.

Durham and Jones attribute the lack of interest in black western history to the growing racism of the period. They state that "the decade following 1900 has frequently been called the 'nadir' of [w]hite-Negro relations in American," a view confirmed by C. Van Woodward in The Strange Career of Jim Crow, among others. ${ }^{22}$ One might assume that this alleged traditional oversight of black cowboys in the early twentieth century literature carried over into the mass media of the second half of the twentieth century thereby explaining the gross underrepresentation of black cowboys in film depictions of the West. Durham and Jones, however, assert,

writers and casting directors who have studied the old West and who know something of its diversity believe that they must respect the ignorance of their audience.... They fear that the accurate representation of the Negro's role in the opening of the West would paradoxically seem to be a falsification of history. ${ }^{23}$

Durham and Jones explicitly attempt to return black cowboys to their rightful place in the overall story of the West. They claim that twentieth-century racism has "fenced out" the Black from history when, in actuality, "the West once nearly approached the democracy that [Americans] are still striving to achieve..." $(3,229)$. This view-that racist attitudes after the West's settlement have eroded understanding of what was a democratic place and time, and that restoring Blacks to Western history will restore an appreciation of that democracy-locates Durham 
and Jones in what Lawrence B. deGraaf calls "the recognition school" of historians. The members of this school accept, for the most part, the Tumerian vision of frontier democracy and simply wish to recognize Blacks as part of that vision. ${ }^{24}$

Others maintain a radically different view. Members of what deGraaf calls "the racism school," contend that when the role of Blacks in the West is clearly established, the notion that the West was democratic will have to be abandoned. The West, these scholars believe, was no more egalitarian than the rest of American society.

deGraaf suggests that both perspectives reveal biases. Pre1960s scholars suffered "blindness ... to ethnic history ... due to their infatuation with the ideas of Frederick Jackson Turner," but more recent scholars who employ themes of racism are influenced too often by "the climate of opinion in the 1960s...." deGraaf concludes by calling for "more studies"; he convincingly argues that historians need to do more comparative work regarding the various ethnic peoples in the old West and the legacies that they have left. ${ }^{25}$

Indeed, much work does remain to be done. As the case of the missing Black cowboys indicates, ignorance of significant aspects of history can seriously impair reasoned interpretation, and misguided paradigms, combined with mythologized portrayals in mass media, can be exceptionally difficult to rectify. Fortunately, and at long last, new work on this neglected topic is beginning to emerge.

Ironically, it has taken another professor of English, Blake Allmendinger, to begin unraveling some of the erroneous but often cited work by Durham and Jones, the two literature professors who resurrected the topic of black cowboys a generation earlier. Allmendinger's 1993 article in the Journal of American Culture sharply criticizes Durham and Jones. He calls their The Negro Cowboys "a 'researched' work which seemed pathfinding [in 1965] but which now reads like nothing more than a series of plot summaries about famous black cowboys. ${ }^{26}$ He notes that they also published a children's book in 1965 in which their chapter on Deadwood Dick (the nickname of the black cowboy Nat Love) reads just as it does in the ostensibly scholarly text. He also accuses Durham and Jones of whitewashing Nat Love by disregarding Love's later career as a Pullman porter; a black man serving white passengers would raise uncomfortable issues of black servitude.

William Loren Katz, who published the aforementioned The Black West in 1971, published Black Indians: A Hidden Heritage in 1986. In his account of the largely unacknowledged African American heritage of many American Indians, he takes Durham and Jones to task for their "distorted" account of Blacks' role in the West. Their statement that "for every Negro renegade who joined against the white man, a company of Negro soldiers fought the Indians' ... understates the number of Black Indians by hundreds of thousands. It also suggests slaves should remain loyal to their owners and praises those who 'fought the Indians."m27 
An examination of Durham and Jones' bibliography suggests that the authors accepted too credulously many cattlemen's personal accounts. Typically mixtures of fact and bluster, these autobiographical accounts make entertaining reading but are problematic sources for historians. Unfortunately many who followed Durham and Jones simply reproduced their sometimes inaccurate information. For example, Allmendinger reveals in his 1992 monograph, The Cowboy: Representations of Labor in an American Work Culture, that Durham and Jones' figure of five thousand black cowboys-a figure that subsequently made its way into at least five other books - was based solely on a single cattleman's guess. "Other than rephrasing the claims that Durham and Jones have made, scholars seldom introduce new information conceming black cowboys and the work that they did," Allmendinger states. When The Negro Cowboys was republished in 1983 by the University of Nebraska's Bison Books, it included no new foreword or other more recent material, indicating either the paucity of new work in the intervening eighteen years, the unwillingness of the authors to update their work, or both. ${ }^{28}$

Richard Slatta's (1990) more recent comparative study, Cowboys of the Americas, discussed above, also earns Allmendinger's criticism. Slatta (1990) writes that Nat Love eamed his nickname, Deadwood Dick, at an Independence Day celebration in Deadwood, Arizona, when Love's autobiography clearly states that it took place in Deadwood, South Dakota. Slatta (1990) also incorrectly identifies Love's birthplace as Ohio; in fact, it was Tennessee. Such sloppiness with details calls into question Slatta's (1990) broader interpretations and conclusions, indicating that even the most recent scholarship on black cowboys is marred. ${ }^{29}$

Two ostensibly comprehensive and long works on the American West published this decade exemplify most recent scholarship which continues to provide little or no information about black cowboys. The landmark work, The Oxford History of the American West (1994), merely mentions once in more than 800 pages that a "considerable minority" of African American cowboys worked in Texas and Oklahoma. ${ }^{30}$ This single, brief mention appears in a chapter written by renowned Western historian Richard White. Ironically, his own recent work, "It's Your Misfortune and None of My Own": A History of the American West (1991), despite running more than 600 pages, bears no reference at all to Black cowboys. ${ }^{31}$ This omission is particularly puzzling given White's statement in the book that the "new minority histories" partly inspired his re-examination of the American West (xvii). In fact, White's continuing suggestion that most cowboys were white requires more evidence given the lack of quantitative data; if, say, 25 percent of cowboys were black and 30 percent were Mexican or Mexican American, no racial group would have constituted a majority. 
Considering the continuing paucity of work on the black West and, moreover, the unreliability of the work that has been done, Allmendinger rightly states, "Scholarship has not done a sufficient job of illustrating the labor that black cowboys enacted. ${ }^{\text {.32 }}$ Allmendinger's own work focuses on expressive forms of cowboy culture and does not attempt to provide the historical record he finds lacking in previous work. At least he exposes several important flaws in existing historiography on the subject, an important first step toward establishing a fuller historical record.

Historians should resume the search for the truth about black cowboys in the context of the social and economic crises that brought them to the West and that greeted them once there. Perhaps a forthcoming book by Quintard Taylor, In Search of the Racial Frontier and another edited by Monroe Lee Billington and Roger D. Hardaway, African Americans of the Western Frontier, will contribute to that search. ${ }^{33}$

\section{NOTES}

'The statistics regarding numbers of black cowboys are newly contested. Philip Durham and Everett L. Jones estimate that about five thousand cowboys in the West at the end of the nineteenth century were black ("Slaves on Horseback," Pacific Historical Review 33 [November 1964: 409), but Blake Allmendinger ("Deadwood Dick," Journal of American Culture 16 [Winter 1993]: 88) reminds us that William W. Savage, Jr., casts doubt on their figure and that no one has convincingly established an accurate estimate.

2Jack D. Forbes, Afro-Americans in the Far West: A Handbookfor Educators (Berkeley, CA: Far West Laboratory for Educational Research and Development, 1969), 34.

${ }^{3}$ Eric Foner, Reconstruction: 1863-1877 (New York: Harper \& Row, 1988), 598.

${ }^{4}$ Robert G. Athearn, In Search of Canaan: Black Migration to Kansas, 1879-80 (Lawrence: Regents Press of Kansas, 1978); Nell Irvin Painter, Exodusters: Black Migration to Kansas after Reconstruction (New York: Knopf, 1977).

5Lawrence B. deGraaf, "Recognition, Racism, and Reflections on the Writing of Western Black History," Pacific Historical Review 44 (February 1975): 24.

${ }^{6}$ Philip Ashton Rollins, The Cowboy (New York: C. Scribner's Sons, 1922), 22; Walter Prescott Webb, The Great Plains (Lincoln: University of $\mathrm{Ne}$ braska Press, 1931). 
7deGraaf, 22.

${ }^{8}$ Robert R. Dykstra, The Cattle Towns (Lincoln: University of Nebraska Press, 1968).

${ }^{9}$ Richard A. Barlett, The New Country: A Social History of the American Frontier, 1776-1890 (New York: Oxford University Press, 1974), 130.

${ }^{10}$ Rodman W. Paul, The Far West and the Great Plains in Transition, 1859-1900 (New York: Harper \& Row, 1988), 193.

"Paul, 128.

${ }^{12}$ David Dary, Cowboy Culture: A Saga of Five Centuries (Lawrence, KS: University of Kansas Press, 1981), 69.

13Philip Durham, "The Negro Cowboy," American Quarterly 7 (Fall 1955): 291-301; Philip Durham and Everett L. Jones, "Negro Cowboys," American West 1 (Fall 1964); Philip Durham and Everett L. Jones, The Negro Cowboys (Lincoln: University of Nebraska Press, 1983; originally published in 1965).

${ }^{14}$ Philip Durham and Everett L. Jones, The Negro Cowboys, v.

${ }^{15}$ For example: "All the real cowboys-black, brown, red and whiteshared the same jobs and dangers." Durham and Jones, The Negro Cowboys, 1. William Loren Katz argues in The Black West (Garden City, NY: Doubleday, 1971) that racism characterized much of the West.

${ }^{16}$ Richard W. Slatta, Cowboys of the Americas (New Haven, CT: Yale University Press, 1990), 159, 168.

${ }^{17}$ Ray Allen Billington, foreword to Black in the West, by W. Sherman Savage (Westport, CT: Greenwood Press, 1976), x-xi.

${ }^{18}$ Billington, $x i$.

${ }^{19}$ Katz, The Black West, Kenneth L. Porter, The Negro on the American Frontier (New York: Amo Press, 1971), 7.

${ }^{20}$ Savage, Blacks in the West, 10.

${ }^{21}$ Durham and Jones, The Negro Cowboys, 220-1. 
22Durham and Jones, The Negro Cowboys, 223; C. Vann Woodward, The Strange Career of Jim Crow, 3rd ed. (New York: Oxford University Press, 1974), 96.

23Durham and Jones, The Negro Cowboys, 229.

${ }^{24}$ deGraaf, 35-6. See Frederick Jackson Turner, The Significance of the Frontier in American History (New York: Ungar, 1963).

${ }^{25}$ deGraaf, 50-1. A good example of the credulous Turnerian perspective is George R. Woolfolk, "Turner's Safety Valve and Free Negro Westward Migration," Pacific Northwest Quarterly 56 (July 1965).

${ }^{26}$ Allmendinger, “Deadwood Dick": 87.

${ }^{27}$ William Loren Katz, Black Indians: A Hidden Heritage (New York: Atheneum, 1986), 5.

${ }^{28}$ Black Allmendinger, The Cowboy: Representations of Labor in an American Work Culture (New York: Oxford University Press, 1992), 159160.

${ }^{29}$ Allmendinger, "Deadwood Dick": 89; Richard W. Slatta, Cowboys in the Americas (New Haven, CT: Yale University Press, 1990), 169; Nat Love, The Life and Adventures of Nat Love (Salem, NH: Ayer, 1992; originally published 1907), 7, 97.

${ }^{30}$ Richard White, "Animals and Enterprise," in Clyde A. Milner II, Carol A. O'Connor, and Martha A. Sandweiss, eds., The Oxford History of the American West (New York: Oxford University Press, 1994), 262.

${ }^{31}$ Richard White, "It's Your Misfortune and None of My Own": A History of the American West (Norman: University of Oklahoma Press, 1991).

${ }^{32}$ Allmendinger, The Cowboy, 12.

${ }^{33}$ Quintard Taylor, In Search of the Racial Frontier: African Americans in the American West, 1528-1990 (New York: Norton, forthcoming); Monroe Lee Billington and Roger D. Hardaway, eds., African Americans on the Western Frontier (Niwot: University Press of Colorado, forthcoming). 